\title{
LOCAL WISDOM IN UTILIZING PEAT SWAMP SOIL AND WATER TO IMPROVE QUALITY OF GELAM WOOD
}

\author{
${ }^{1}$ Wahyu Supriyati, ${ }^{1}$ Alpian, ${ }^{2}$ T.A. Prayitno, ${ }^{2}$ Sumardi, ${ }^{2}$ Sri Nugroho Marsoem \\ ${ }^{1}$ Forestry Department, Palangka Raya University, Palangka Raya, Central Kalimantan \\ Email: wahyu plk@yahoo.com \\ ${ }^{2}$ Forestry Faculty, Gadjah Mada University, Yogyakarta
}

\begin{abstract}
ABSTRAK
Local wisdom in utilizing swamp soil and water to improve the quality of gelam wood in Central Kalimantan becomes an interesting phenomenon. Improving the quality of wood can economize on the use of wood, which in turn preserves the forests in peat swamp lands. Gelam (Melaleuca sp.) woods that are mostly found in peat swamp forests can be used as piles/stakes in swamp soil, and they are durable for decades. The general objective of this study was to provide a scientific explanation of the effect of peat swamp soil and water on improving the quality of gelam wood either in barked and barkless conditions. This study was conducted by taking gelam trees that grew in Central Kalimantan. It was carried out for 18 months, and investigated the barked/barkless woods, media (swamp water, freshwater, peat swamp soil, and sandy soil) and 3 lengths of burying times. Wood properties analyzed were physical and mechanical properties. The standard of physical-mechanical property tests referred to British Standard 373.

The results showed that the interaction between bark factor (A) and media (B) affected specific gravity. Barked wood produced the highest spesific gravity in swamp water medium. Water media (swamp and fresh water) improved the wood's specific gravity more than soil media (swamp and sandy soil). The highest values of hardness, stress on Proportional Limit, and Modulus of Elasticity were in the medium of swamp soil. The improvement of the quality of gelam woods, which were either buried or used as stakes/piles, was allegedly resulted from the swamp water infiltrating into gelam woods that thereby increased the specific gravity.
\end{abstract}

Keywords: burial, gelam, local wisdom, mechanical physical properties, peat swamp soil and water

\section{INTRODUCTION}

Communities have local wisdom in
utilizing natural resources in their surroundings. One of the communities is the community living in Central Kalimantan who uses the medium of peat swamp water to immerse the wood. The improvement of wood quality can economize on the use of wood, which in turn preserves the forests in peat swamp lands.

Gelam (Melaleuca sp.) is mostly found in peat swamp forests. People use gelam as stake/pile. Gelam's lifetime as the stake can reach several decades despite its durable class 3 , according to the Indonesian durable class standard. This class means that gelam has only 3 years of lifetime when used in a direct contact with the ground.

Gelam tree is a species of Myrtaceae family which grows in swampy lowland areas (coastal swampy lowlands) in some countries such as Indonesia, Malaysia, Singapore, Thailand, and northern Australia. Melaleuca family which include over 200 species have a fairly wide distribution of growing place; most are endemic to Australia, and some species grow in Malaysia and New Caledonia (Quinn et al., 1998). In Indonesia, gelam has a fairly spacious growing place distribution including the east coast of Sumatra and Kalimantan. Based on the Dotgrid calculation on the map of area direction and function which was conducted by Watershed Management Center (BPDAS) Kahayan (2007), it was estimated that gelam area in Central Kalimantan was more than 75,000 ha. In its natural growing place, gelam is found in open forests, shrub lands, especially along rivers and swamp edges. This type of plant is known for having morphological plasticity in the form of aquatic heterophylly so it can grow in wet and dry habitats (Quinn et al., 1998). The ability to grow in open lands, waterlogged areas or in the lands with high acidity, makes this type often regarded as a pioneer species (Rachmanady et al., 2004; Sayuto, 2004; Mulyanto et al., 2000; Suyanto and 
Khususiyah, 2004; Suyanto et al., 2007; Chokkalingam, et al., 2007) in accordance with the nature and ability to grow.

The purpose of this study was to provide a scientific explanation about the local wisdom in utilizing swamp soil and water that was to find out the effects of the burying media and the presence of bark in improving the quality of wood (mechanical physical properties).

The benefit of this study is to produce scientific information about the effects of peat swamp soil and water media in storing logs on the wood quality. The results would be used as guidelines for the utilization of peat swamp soil and water media for the efficiency of wood uses in the future.

The study of gelam properties is expected to be useful for the community and the government in Central Kalimantan to meet the wood supply for the piles/stakes. The results of this study can ecologically and economically improve the development of gelam utilization.

\section{MATERIALS AND METHODS}

This study was conducted in Central Kalimantan on gelam samples, barked and barkless, with diameter $<10 \mathrm{~cm}$. They had been buried in 4 types of media for 0 month (control), 6 months, 12 months with 3 replications. The number of samples was $2 x$ $4 \times 2 \times 3=48$ logs. The tests included the test for wood mechanical physical properties on the basis of the testing standards that had been determined.

The sample burial was conducted in soil and water media. Supporting data on the analysis of water medium were obtained from laboratory tests at the Center for Environmental Health Engineering (BBKTL), Yogyakarta.

Table 1. Average values of chemicals in water media

\begin{tabular}{ccccccc}
\hline Sample of water & $\mathrm{pH}$ & Silica $(\mathrm{mg} /$ /iter $)$ & Sulfate & Zink & Nitrate & Nitrite \\
\hline Swamp water & 3.61 & 24.014 & 21 & 0.2049 & 1.236 & 0.0888 \\
Fresh water & 5.65 & 47.908 & 26 & 3.2153 & 6.228 & 0.0201 \\
\hline
\end{tabular}

Table 2. Chemical and physical analyses of soil media

\begin{tabular}{|c|c|c|c|c|c|c|c|c|c|c|}
\hline \multirow{2}{*}{ Code } & \multicolumn{2}{|c|}{$\begin{array}{l}\text { Moisture } \\
\text { Content } \\
\end{array}$} & \multirow{2}{*}{$\begin{array}{r}\mathrm{pH} \\
\mathrm{H} 20\end{array}$} & \multirow{2}{*}{$\begin{array}{l}\text { EC } \\
\mu S\end{array}$} & \multirow{2}{*}{$\begin{array}{l}\text { C } \\
\%\end{array}$} & \multirow{2}{*}{$\begin{array}{r}\text { OM } \\
\%\end{array}$} & \multirow{2}{*}{$\begin{array}{c}\mathrm{N} \\
\text { tot } \\
\%\end{array}$} & \multicolumn{3}{|c|}{ Texture } \\
\hline & $\begin{array}{c}0.5 \\
\mathrm{~mm}\end{array}$ & $\begin{array}{r}2.0 \\
\mathrm{~mm}\end{array}$ & & & & & & $\mathrm{cl}$ & ds & $\mathrm{Sd}$ \\
\hline 11 & 5.81 & 7.28 & 4.46 & 12.25 & 9.24 & 15.94 & 0.50 & 48.90 & 37.16 & 13.94 \\
\hline 12 & 10.31 & 10.10 & 4.05 & 8.25 & 8.60 & 14.83 & 0.39 & 48.27 & 39.55 & 12.18 \\
\hline 13 & 19.85 & 22.61 & 3.69 & 12.50 & 11.97 & 20.63 & 0.54 & 47.84 & 30.31 & 21.85 \\
\hline 14 & 6.58 & 6.35 & 3.56 & 18.50 & 8.98 & 15.48 & 0.26 & 53.22 & 35.03 & 11.75 \\
\hline 21 & 0.35 & 0.18 & 7.70 & 18.15 & 0.19 & 0.34 & 0.06 & 2.04 & 2.73 & 95.23 \\
\hline 22 & 0.37 & 0.22 & 7.87 & 16.10 & 0.16 & 0.27 & 0.04 & 2.14 & 1.46 & 96.39 \\
\hline 23 & 0.50 & 0.06 & 7.57 & 14.00 & 0.13 & 0.23 & 0.03 & 1.56 & 2.74 & 95.69 \\
\hline 24 & 0.41 & 0.20 & 7.61 & 15.24 & 0.11 & 0.19 & 0.05 & 1.72 & 1.8 & 96.47 \\
\hline
\end{tabular}

The results of water analysis are presented in Table 1. Data of the soil chemical analysis (Table 2) were obtained from the study at the Laboratory of Soil Science, Gadjah Mada University.

Test sample making.There were 48 Gelam trees, 24 trees with bark and 24 barkless, buried in four different burying media, namely swamp water, non-swamp water, swamp soil, and non-swamp soil (sandy soil) for 0 month (control), 6 months and 12 months. In each treatment, 3 trees (replication) were taken randomly. The sampling is shown in Figure 1. 
Burial treatment

12 months

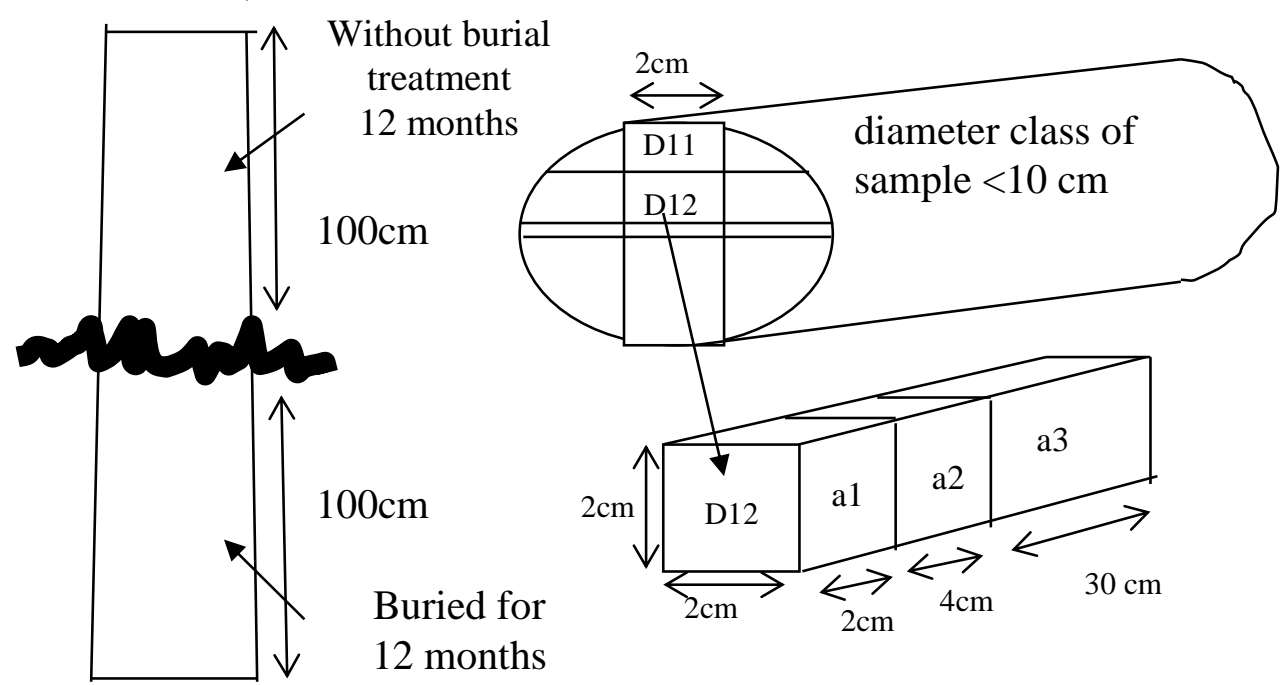

Description: $\mathrm{a}=$ the base of Gelam;

a1 = sample of water content/specific gravity

a2 = sample of hardness

a3 = sample of static arch firmness

Figure 1. Wood Physical and Mechanical Sampling

Tree was cut as low as possible $(50 \mathrm{~cm}$ above the ground surface), and the branchfree trunk was taken, cut into the respective length of $2 \mathrm{~m}$, and then buried upright; a half part $(1 \mathrm{~m})$ was buried in the four media for 1 year and the other half $(1 \mathrm{~m})$ was not buried (control). The other trees were buried for 6 months. The burying media are presented in Figure 1.

The model of statistical design used in the study was equation (3). The results obtained through the $\mathrm{F}$ test had not been able to provide the information on which treatment was more significant than other treatments.
Therefore, it was necessary to make the comparison using SAS. Data analysis was performed to determine the significance of the factors $A, B, C$ and factor interaction $A B C$.

The design used in the study was a completely randomized design with $2 \times 4 \times 3$ factorial experiments (Sudjana, 2002).

\section{RESULTS AND DISCUSSION}

This study was conducted on a sample diameter class $<10 \mathrm{~cm}$ of barked and barkless trees. Samples were buried in 4 types of media and for 3 different lengths of time. 

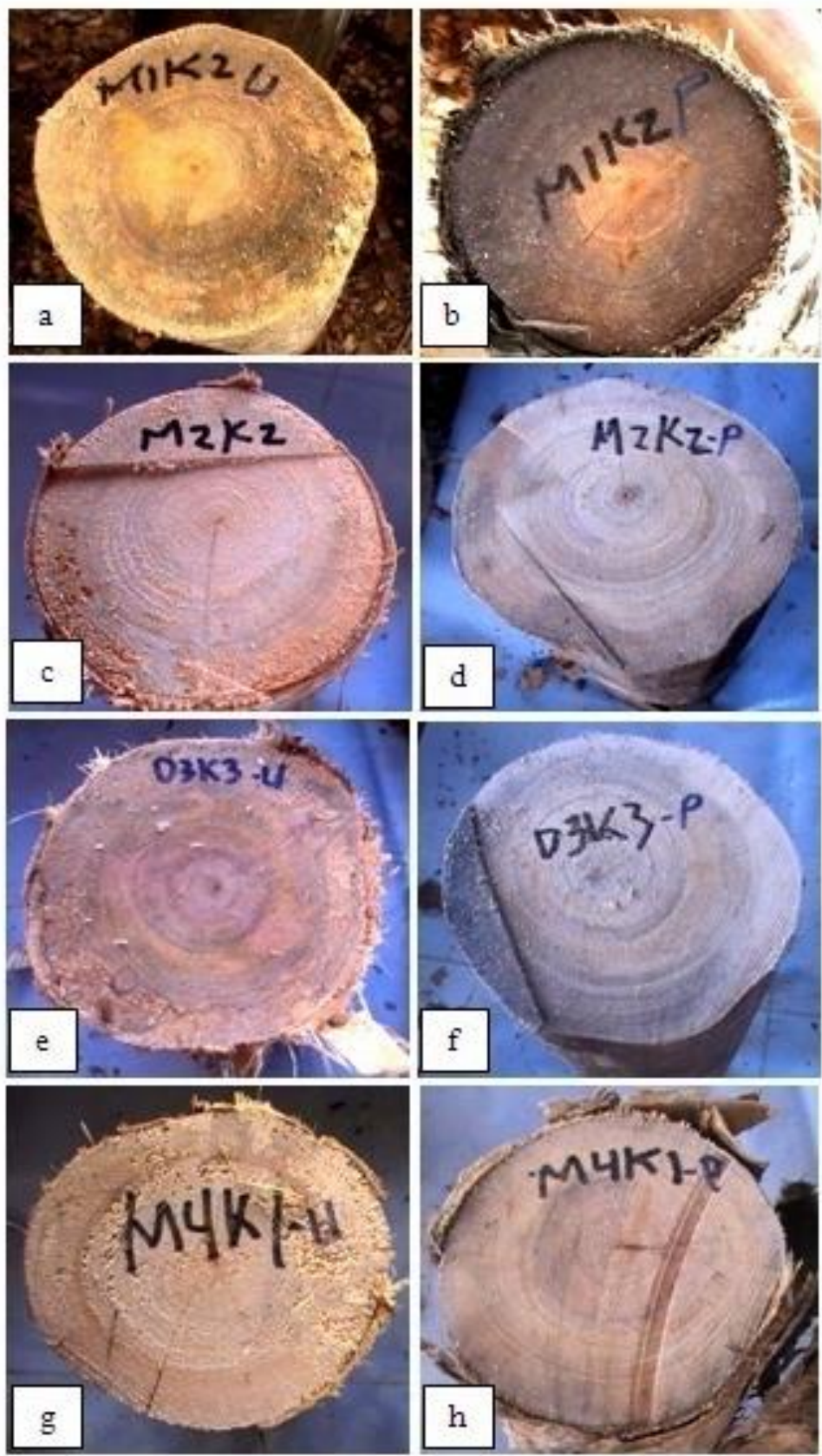

Figure 2. Appearance of barked stakes/piles a) swamp water media, without burial, b) swamp water media, buried for 12 months; c) fresh water media, without burial; d) freshwater media, buried for 12 months; e) peat soil media, without burial; f) peat soil media, buried for 12 months g) sandy soil media, without burial; h) sandy soil media, buried for 12 months. 

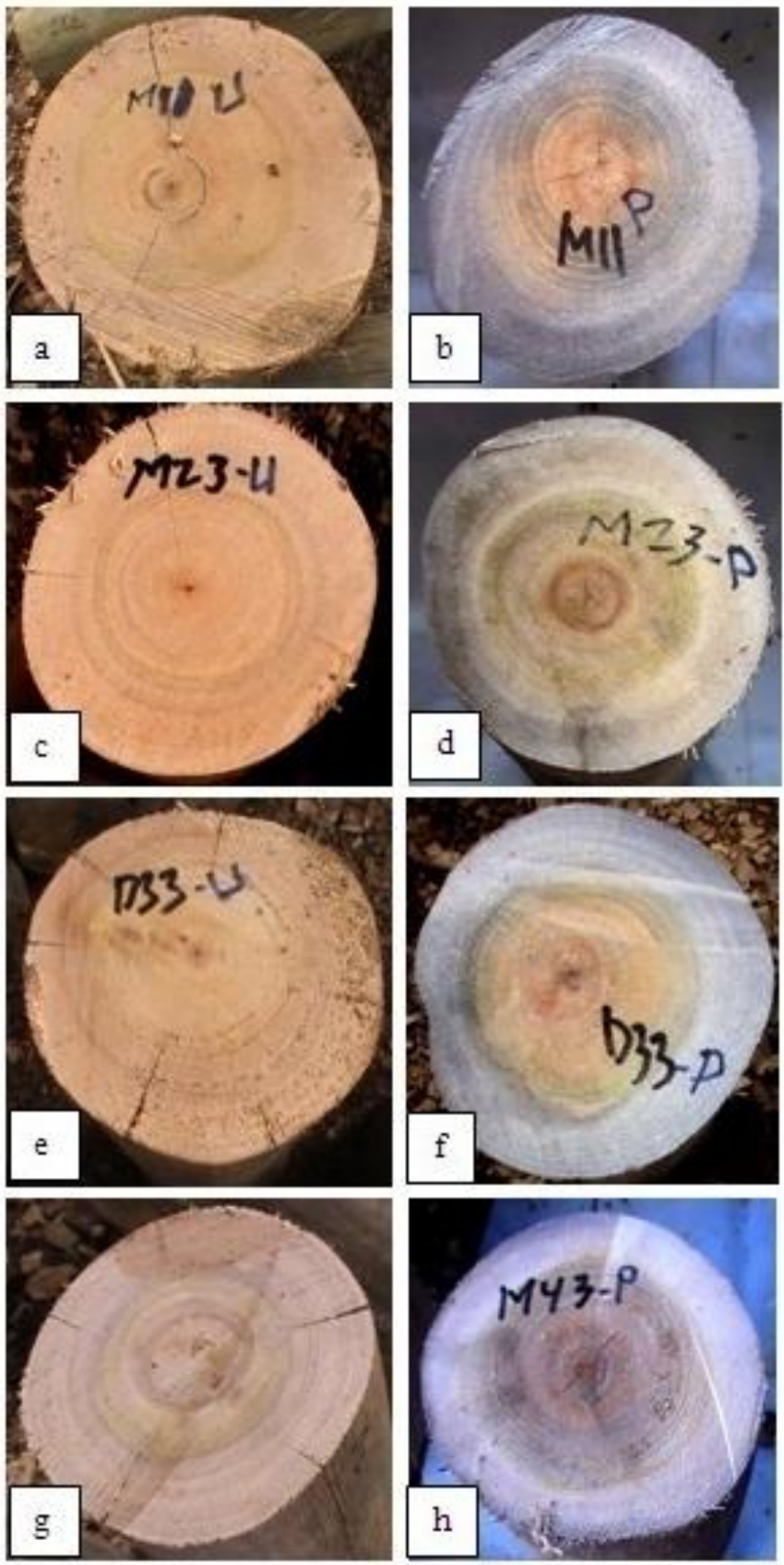

Figure 3. Appearance of barkless stakes/piles a) swamp water media, without burial, b) swamp water media, buried for 12 months; c) fresh water media, without burial; d) freshwater media, buried for 12 months; e) swamp soil media, without burial; f) swamp soil media, buried for 12 months $\mathrm{g}$ ) sandy soil media, without burial; h) sandy soil media, buried for 12 months

The average values of physical characteristics observed in the study are presented in Table 3. Physical properties include specific gravity (SG) and moisture content (MC). 
Wahyu Supriyati, Alpian, T.A. Prayitno, Sumardi, Sri N. Marsoem: Local Wisdom In

Table 3. Average values of SG and MC of gelam wood based on condition, media and length of burying time.

\begin{tabular}{|c|c|c|c|c|c|c|c|c|}
\hline C & $\mathrm{M}$ & $\mathrm{L}$ & $r$ & Wet SG & ADSG & ODSG & Wet MC (\%) & ADMC (\%) \\
\hline \multirow[t]{3}{*}{ C1 } & M1 & L1 & 12 & 0.51 & 0.54 & 0.62 & 69.56 & 13.40 \\
\hline & & L2 & 12 & 0.58 & 0.63 & 0.66 & 89.72 & 13.38 \\
\hline & & L3 & 12 & 0.55 & 0.60 & 0.65 & 82.54 & 13.68 \\
\hline \multicolumn{4}{|c|}{ Average } & 0.55 & 0.59 & 0.65 & 80.61 & 13.49 \\
\hline \multirow[t]{4}{*}{ C1 } & M2 & L1 & 12 & 0.53 & 0.57 & 0.62 & 86.75 & 13.55 \\
\hline & & L2 & 12 & 0.54 & 0.62 & 0.67 & 85.18 & 13.05 \\
\hline & & L3 & 12 & 0.53 & 0.56 & 0.60 & 91.30 & 13.72 \\
\hline & & & & 0.53 & 0.58 & 0.63 & 87.74 & 13.44 \\
\hline \multirow[t]{3}{*}{ C1 } & M3 & $\mathrm{L} 1$ & 12 & 0.53 & 0.57 & 0.61 & 78.84 & 13.46 \\
\hline & & L2 & 12 & 0.58 & 0.63 & 0.69 & 81.10 & 13.58 \\
\hline & & L3 & 12 & 0.56 & 0.62 & 0.67 & 82.82 & 13.27 \\
\hline \multicolumn{4}{|c|}{ Average } & 0.56 & 0.61 & 0.66 & 80.92 & 13.44 \\
\hline \multirow[t]{3}{*}{ C1 } & M4 & $\mathrm{L} 1$ & 12 & 0.50 & 0.53 & 0.57 & 75.25 & 14.04 \\
\hline & & L2 & 12 & 0.57 & 0.61 & 0.65 & 87.59 & 13.36 \\
\hline & & L3 & 12 & 0.54 & 0.57 & 0.60 & 76.36 & 13.50 \\
\hline \multicolumn{3}{|c|}{ Average } & & 0.54 & 0.57 & 0.61 & 79.73 & 13.63 \\
\hline \multirow[t]{3}{*}{$\mathrm{C} 2$} & \multirow[t]{3}{*}{ M1 } & L1 & 12 & 0.58 & 0.61 & 0.67 & 57.68 & 13.63 \\
\hline & & L2 & 12 & 0.59 & 0.64 & 0.68 & 86.06 & 13.51 \\
\hline & & L3 & 12 & 0.59 & 0.65 & 0.71 & 70.16 & 13.42 \\
\hline \multicolumn{4}{|c|}{ Average } & 0.59 & 0.63 & 0.68 & 71.30 & 13.72 \\
\hline \multirow[t]{3}{*}{$\mathrm{C} 2$} & \multirow[t]{3}{*}{ M2 } & L1 & 12 & 0.56 & 0.61 & 0.67 & 51.36 & 13.72 \\
\hline & & L2 & 12 & 0.58 & 0.63 & 0.67 & 89.88 & 13.23 \\
\hline & & L3 & 12 & 0.59 & 0.64 & 0.69 & 70.05 & 13.65 \\
\hline \multicolumn{4}{|c|}{ Average } & 0.58 & 0.63 & 0.67 & 70.43 & 13.52 \\
\hline \multirow[t]{3}{*}{$\mathrm{C} 2$} & \multirow[t]{3}{*}{ M3 } & L1 & 12 & 0.55 & 0.59 & 0.63 & 85.08 & 13.47 \\
\hline & & L2 & 12 & 0.60 & 0.63 & 0.67 & 84.28 & 13.52 \\
\hline & & L3 & 12 & 0.55 & 0.59 & 0.63 & 69.64 & 13.72 \\
\hline \multicolumn{4}{|c|}{ Average } & 0.57 & 0.60 & 0.64 & 79.67 & 13.57 \\
\hline \multirow[t]{3}{*}{$\mathrm{C} 2$} & M4 & L1 & 12 & 0.54 & 0.57 & 0.60 & 73.37 & 13.81 \\
\hline & & L2 & 12 & 0.56 & 0.58 & 0.61 & 96.00 & 13.39 \\
\hline & & L3 & 12 & 0.54 & 0.57 & 0.61 & 83.23 & 13.55 \\
\hline \multicolumn{4}{|c|}{ Average } & 0.55 & 0.57 & 0.61 & 84.20 & 13.58 \\
\hline \multicolumn{3}{|c|}{ Total $n$} & 288 & & & & & \\
\hline \multicolumn{3}{|c|}{ SD } & & 0.05 & 0.06 & 0.06 & 14.33 & 0.49 \\
\hline
\end{tabular}

Notes: $\mathrm{C}=$ condition with/without bark; $\mathrm{M}=$ media; $\mathrm{L}=$ length of burying time; $\mathrm{r}$ = replication; $\mathrm{C} 1$ = with bark, $\mathrm{C} 2$ = without bark; M1 = swamp water; M2 = fresh water; M3 = swamp soil; M4 = sandy soil; L1 = 0 month (control); L2 = 6 months, and L3 = 12 months; $n=$ number of samples; SD = standard deviation.

The highest average of ODSG in barkless condition was in swamp water media. The results of statistical analysis of wood physical properties can be seen in Table 4 . The results showed that there was no significant difference in the interaction between these three factors towards specific gravity.

The average value of wet $M C$ in the barked wood was higher than in the barkless wood. The increasing of wet MC in barked wood $(82.05 \%)$ was higher than in barkless wood $(76.38 \%)$ about $7.42 \%$. This was due to the properties of the barked gelam which was relatively watertight so that it held out the water.
The average values of water content based on the burying media successively from the largest one were M4 (sandy soil), M3 (swamp soil), M2 (freshwater) and M1 (swamp water ). The pattern of changes in the lowest wet MC was found in the woods that were not buried. This was allegedly due to the unburied woods were left to dry exposed to wind so the wet MC decreased. The buried woods were more capable of holding moisture content of barked gelam woods. Moreover, the barked gelams were relatively able to hold reduced moisture. 
Table 4. Varian analysis of factors of bark, media and length of burying time towards parameters of physical properties

\begin{tabular}{|c|c|c|c|c|c|c|}
\hline Factor & Df & Wet BJ & ADSG & ODSG & Wet MC & ADMC \\
\hline A & 1 & ** & $\star *$ & $\star *$ & $\star *$ & ns \\
\hline B & 3 & ** & ** & ** & ** & ns \\
\hline C & 2 & ** & ** & ** & ** & ** \\
\hline$A B$ & 3 & * & ** & ** & ** & ns \\
\hline$A C$ & 2 & Ns & $* *$ & ** & ** & ns \\
\hline $\mathrm{BC}$ & 6 & Ns & Ns & ns & ** & $* \star$ \\
\hline $\mathrm{ABC}$ & 6 & Ns & Ns & ns & ** & ns \\
\hline
\end{tabular}

Notes: $\mathrm{A}=$ condition with/without bark, $\mathrm{B}=$ media; $\mathrm{C}=$ length of burying time;

${ }^{*} /{ }^{* *}=$ significantly different/very significant, $\mathrm{ns}=$ not significant.

The effect of bark was assumed to occur because the barked gelam was watertight thereby blocking the infiltration/effects of other substances into the wood. The outside effects to the wood can affect the wood specific gravity, Akahane et al. (2004).

Akahane et al. (2004) proved that the hot spring water filled the pores of the wood and saved silica into the cell wall. It showed the changes in the wood which reached $40 \%$ of its weight in the period of 7 years. In their study, they did not include barked woods so that the infiltration of substances into the wood was easier. The highest specific gravity (SG) was found in swamp water media (M1), that was successively followed by swamp soil (M3), freshwater (M2) and sandy soil (M4). Further HSD/Tukey test showed the difference between the M1 and M3 M4. The wood specific gravity (SG) in sandy soil media (M4) differed significantly from the other media. The increse in wood SG in water swamp (0.66) compared to sandy soil (0.61) was $8.20 \%$.

Interaction between bark factor $(\mathrm{A})$ and media (B) affected the value ODSG. The ODSG average value tended to be higher in the wood without bark (0.651) than in barked wood (0.63). The change in increasing ODSG value in buried barkless woods compared to barked woods was $2.36 \%$. Barked woods producing the highest ODSG value was buried in swamp water media (21), the lowest value was in sandy soil media. This was presumably due to the sandy soil condition that allowed microorganisms to live, resulting in decreasing ODSG value.

The interaction between bark and length of burying time affected ODSG. The highest interaction was in barked woods buried for 6 months. Statistically, the specific gravity of buried woods (L2 and L3) differed significantly from the wood that was not buried (L1). Length of burying time affected SG, with the lowest one in L1. Further test for ODSG showed no difference between L2 (buried for 6 months) and L3 (12 months). Barked condition without burial allowed microorganisms to live so ODSG became small.

The buried woods had higher SG than the woods which were not buried. The increased SG value of woods with 12 month burial (0.65) toward woods without burial (0.62) was $3.64 \%$. Christienin et al. (2009) stated that carbonization or petrifaction depend on the condition of immersion in an anaerobic environment. Different conditions of media were suspected to cause the different carbonization or petrifaction processes.

Bark significantly influenced wet $M C$, $S G$ and hardness. The highest values of wet MC, SG, hardness and MOR were in barkless woods. This indicated that bark actually reduced the infiltration process of substance from media to wood which encouraged the increasing of the wood SG. It can then be concluded from such a phenomenon that the use of gelam wood as the stake/pile is more advisable in barkless condition when bark is not required as the stabilizer in soft soil (peat swamp). 
Wahyu Supriyati, Alpian, T.A. Prayitno, Sumardi, Sri N. Marsoem: Local Wisdom In

Environmental effects (burying media) found in the increased value of wood ODSG burried in swamp water (M1) rather than in sandy soil (M4) was $8.67 \%$. The difference in level of silica in freshwater media (M2) toward the M4 (sandy soil) was $9.00 \%$ (higher in M2). It was connected with the silica level of wood buried in fresh water which was relatively higher than that of wood buried in swamp water. Despite this difference, the wood silica levels found were not significant. Sulthoni (1988) found out that the starch content of bamboo buried in mud did not change significantly. Changes in starch on bamboo buried in river water was caused by bacteria that lived in the water (Bacillus sp.). These bacteria had the most prominent role in the process of dissolving the starch content of bamboo buried in river water. On the other hand, the $\mathrm{pH}$ of soil and water in the study area (Central Kalimantan) that was relatively low had reduced the number of microorganisms in it (Noor (2001).

In general, the water media (swamp water and freshwater) improved the wood specific gravity more than soil media (swamp soil and sandy soil). The increased quality of gelam as the pile was allegedly caused by the swamp water infiltrating into the wood, that thereby increased its specific gravity.

Tables 5 and 6 show the average wood mechanical properties and ANOVA. The values of hardness seem higher in barkless woods burried in swamp soil.

Table 5. The average values of hardness and static arch firmness of gelam wood based on condition (barked/barkless), media and length of burying time

\begin{tabular}{|c|c|c|c|c|c|c|c|}
\hline C & M & L & $r$ & Hardness & $\begin{array}{l}\text { Stress on PL } \\
\left(\mathrm{Kg} / \mathrm{cm}^{2}\right)\end{array}$ & $\begin{array}{c}\mathrm{MOR} \\
\left(\mathrm{Kg} / \mathrm{cm}^{2}\right)\end{array}$ & $\begin{array}{c}\mathrm{MOE} \\
\left(\mathrm{Kg} / \mathrm{cm}^{2}\right)\end{array}$ \\
\hline \multirow[t]{4}{*}{$\mathrm{C} 1$} & M1 & L1 & 6 & 353.8 & 546.1 & 1143.2 & 120,428 \\
\hline & & L2 & 6 & 411.3 & 672.7 & 1141.9 & 110,198 \\
\hline & & L3 & 6 & 464.3 & 618.2 & 1055.0 & 126,420 \\
\hline & $A v \epsilon$ & $\bar{e}$ C11 & & 409.8 & 612.4 & 1113.4 & 119,015 \\
\hline \multirow[t]{4}{*}{ C1 } & $\mathrm{M} 2$ & L1 & 6 & 272.7 & 646.1 & 1047.3 & 112,263 \\
\hline & & L2 & 6 & 437.5 & 652.0 & 1030.2 & 86,051 \\
\hline & & L3 & 6 & 328.8 & 690.8 & 1185.2 & 140,768 \\
\hline & Ave & e C1I & & 346.3 & 663.0 & 1087.5 & 113,027 \\
\hline \multirow[t]{4}{*}{$\mathrm{C} 1$} & M3 & L1 & 6 & 400.6 & 550.8 & 735.7 & 73,840 \\
\hline & & L2 & 6 & 465.4 & 689.4 & 1091.1 & 110,655 \\
\hline & & L3 & 6 & 526.9 & 594.6 & 1084.1 & 137,379 \\
\hline & Ave & e C11 & & 464.3 & 611.6 & 970.3 & 107,291 \\
\hline \multirow[t]{3}{*}{$\mathrm{C} 1$} & M4 & L1 & 6 & 337.7 & 483.0 & 827.1 & 97,007 \\
\hline & & L2 & 6 & 528.4 & 550.6 & 902.6 & 105,868 \\
\hline & & L3 & 6 & 503.3 & 537.2 & 885.1 & 125,045 \\
\hline & Ave & e C1I & & 456.5 & 523.6 & 871.6 & 109307 \\
\hline \multirow[t]{3}{*}{$\mathrm{C} 2$} & M1 & L1 & 6 & 476.0 & 521.2 & 926.6 & 103,409 \\
\hline & & L2 & 6 & 493.8 & 596.5 & 1115.5 & 103,640 \\
\hline & & L3 & 6 & 563.8 & 556.5 & 1177.4 & 125,906 \\
\hline & Ave & e C2l & & 511.2 & 558.1 & 1073.3 & 110,985 \\
\hline \multirow[t]{3}{*}{$\mathrm{C} 2$} & $\mathrm{M} 2$ & L1 & 6 & 389.9 & 590.6 & 1054.4 & 107,868 \\
\hline & & L2 & 6 & 461.3 & 542.3 & 916.3 & 94,364 \\
\hline & & L3 & 6 & 472.7 & 631.2 & 1103.8 & 140,423 \\
\hline & Ave & e C21 & & 441.3 & 588.0 & 1024.8 & 114,218 \\
\hline \multirow[t]{3}{*}{$\mathrm{C} 2$} & M3 & $\mathrm{L} 1$ & 6 & 433.6 & 602.1 & 924.8 & 120,299 \\
\hline & & L2 & 6 & 572.1 & 657.3 & 1171.4 & 116,406 \\
\hline & & L3 & 6 & 537.7 & 648.0 & 1156.2 & 132,536 \\
\hline \multirow{4}{*}{$\mathrm{C} 2$} & \multicolumn{3}{|c|}{ Average C2M3 } & 514.4 & 635.8 & 1084.1 & 123,080 \\
\hline & M4 & L1 & 6 & 261.0 & 515.0 & 806.0 & 77,043 \\
\hline & & L2 & 6 & 371.3 & 595.2 & 979.2 & 86,721 \\
\hline & & L3 & 6 & 325.7 & 433.8 & 647.3 & 95,319 \\
\hline & & $\mathrm{L}$ & $r$ & Hardness & Stress on PL & MOR & MOE \\
\hline & & $\mathrm{ge} \mathrm{C2}$ & & 319.3 & 514.7 & 810.8 & 86,361 \\
\hline & Tota & & & 288 & 144 & 144 & 144 \\
\hline & SD & & & 102.5 & 100.6 & 195.9 & 24,470 \\
\hline
\end{tabular}


Notes: $\mathrm{C}=$ barked/barkless condition; $\mathrm{M}=$ media; $\mathrm{L}=$ length of burying time; $r$ = replication; $\mathrm{C} 1$ = with bark, $\mathrm{C} 2$ = barkless; $M 1$ = swamp water; $M 2$ = fresh water; $M 3$ = swamp soil; $M 4$ = sandy soil; $L 1=0$ month (control); L2 = 6 months, and L3 = 12 months; $n=$ number of samples; $S D=$ standard deviation; $P L=$ Proportional Limit.

Table 7 Burial toward Parameters of Mechanical Properties

\begin{tabular}{cccccc}
\hline Factor & Df & Hardness & Stress on PL & MOR & MOE \\
\hline A & 1 & $* *$ & Ns & ns & ns \\
B & 3 & $* *$ & $* *$ & $* *$ & $* *$ \\
C & 2 & $* *$ & $*$ & ns & $* *$ \\
AB & 3 & $* *$ & Ns & ns & ns \\
AC & 2 & ns & Ns & $* *$ & $*$ \\
BC & 6 & $* *$ & Ns & $* *$ & $*$ \\
ABC & 6 & $* *$ &
\end{tabular}

Notes: $\mathrm{A}=$ barked/barkless condition, $\mathrm{B}=$ media; $\mathrm{C}=$ length of burying time;

${ }^{*} /{ }^{* *}=$ significantly different/very significant, $\mathrm{ns}=$ not significant.

The interaction among the three factors affected the hardness of wood. The highest value of hardness was found in the barkless wood buried in the swamp soil media. The lowest value of hardness was found in unburied woods. This was in line with the research by Supriyati et al. (2013) on gelam woods buried in different diameter classes. The condition of the soil also reduced the ability of optimum life wood destroying organism (Scheffer, 1987). It was consistent with the pattern of change in SG. Bowyer et al. (2003), Panshin and de Zeeuw (1980) and Wangaard (1950) which stated that the specific gravity affected some wood strength. Further test of the burial effect showed the 6 and 12 month burials did not differ significantly. This was allegedly due to the length of burying time that did not last long between the two treatments, in line with the results of the research by Lionettoa et al. (2013) that found only a little change in burial.

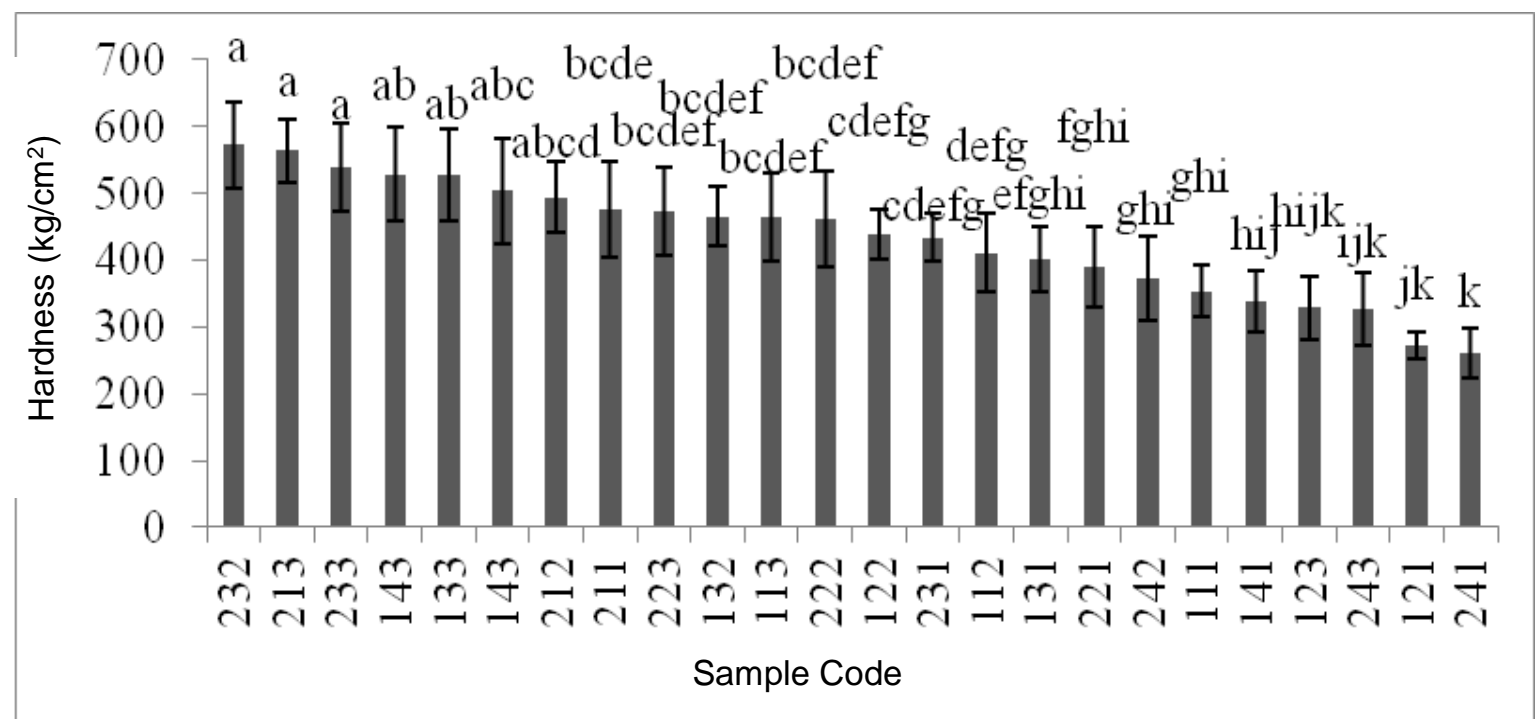

Notes: the first scores are for conditions $=1$ (barked), 2 (barkless); the second scores are for media $=1$ (swamp water); 2 (freshwater); 3 (swamp soil); 4 (sandy soil); the third are for lengths of burying time $=1$ (without burial); 2 (buried for 6 months); 3 (buried for12 months). Value of HSD $=85.117$

Figure 3. Interaction of condition (barked/barkless), media and length of burying time toward hardness 
The change in burial was in accordance with the study by Akahane et al. (2004). They soaked wood samples in water and the samples experienced more strong physical changes due to the increase of the silica value. They proved that the hot spring water filled the pores of the wood and saved silica into the cell wall. Akahane showed that the changes of the wood reached $40 \%$ of its weight in the period of 7 years.

The highest average value of MOR was in barkless woods buried in swamp soil media. The burial in medium 4 (sandy soil) produced the lowest value of MOR and differed significantly from the other media. It had the same pattern with $S G$ and in line with the opinion of Zhang (1996) that described the relationship between $S G$ and mechanical properties. Specific gravity was a measure of wood content; the increase in SG tended to increase the wood strength.

MOE was influenced by the interaction between the three factors. The highest MOE was in the barked woods, medium 2 (fresh water) and buried for 12 months. The MOE in M4 did not differ significantly from that in M1 and $\mathrm{M} 2$.

The smallest average value of MOE was in M4, M1, M2, and M3. MOE was significantly influenced by the burying media. Further tests showed that M3 (peat swamp soil) was significantly different from the other media. MOE was also influenced by the length of burying time. It was associated with the wood condition that allowed the destroying organisms to lower their mechanical strength. Along with that, the fibre stress dropped to more than 15 percent of the fibre, which was caused by fungus, Nicholas (1987).

The average value of the stress on PL was higher in barkless wood than in barked wood. The highest values of hardness, stress on $\mathrm{PL}$ and MOE were found in swamp soil media.

\section{CONCLUSION}

The results showed that the interaction between bark factor $(A)$ and media (B) affected the value of specific gravity (SG).
Barked wood produced the highest specific gravity in the medium of swamp water. Water media (swamp water and freshwater) improved the specific gravity of wood when compared with soil media (swamp soil and sandy soil). The highest values of hardness and stress on Proportional Limit and Modulus of Elasticity were found in the woods buried in swamp soil media. The increase in the quality of immersed gelam woods as the stakes/piles was allegedly resulted from swamp water infiltrating into gelam that thereby increased the specific gravity.

\section{REFERENCES}

Akahane, H., Furuno, T., Miyajima, H., Yoshikawa, T. and Yamamoto, S. (2004). Rapid Wood Silicification in Hot Spring Water: An Explanation of Silicification of Wood During The Earth's History. Sedimentary Geology 169 : 219-228.

Departement of Forestry (2007). Master Plan for Rehabilitation and Conservation of Peat Land Development Areas in Central Kalimantan Province. Center for Forestry Planning and Statistics. Departement of Forestry. Jakarta.

Lionetto, F., Quarta, G., Cataldi, A., Cossa, A., Auriemma, R.. Calcagnile, L. and Frigione, M. (2013). (Case study) Characterization and Dating of Waterlogged Woods from An Ancient Harbor in Italy. Journal of Cultural Heritage (2013). (Article In Press).

Lucejko, J.J., Modugno, F., Ribechini, E. and J.C. del Rio (2009). Characterization of Archaeological Waterlogged Wood by Pyrolytic and Mass Spectrometric Techniques. Analytica Chimica Acta 654 (2009) : 26-34.

Mulyanto, B. and Pratiwi (2002). Characteristics of Gelam and its Habitat in Wetland Ecosystem. Forestry Research and Development Bulletin 3.2 (2002). Departement of Forestry. Jakarta.

Nicholas, D.D. (1987). Wood Deterioration and Its Prevention by Preservative Treatments. Translator: Haryanto Yoedoedibroto. Airlangga University Press. Yogyakarta. 
Wahyu Supriyati, Alpian, T.A. Prayitno, Sumardi, Sri N. Marsoem: Local Wisdom In

Niklas, K.J. (1997). Mechanical Properties of Black Locust (Robinia pseudoacacia L.) Wood. Size and Age-dependent Variations in Sap- and Heartwood. Annals of Botany 79 (1997) : 265272.

Noor, K. (1995). Methods in Using Wooden Piles on Soft land: A case study of Implementation of foundations in Banjarmasin. Retrieved February 3, 2009 from digilib.itb.ac.id/gdl.php?mod=brows e\&op=read\&id=jbptitbpp-gdl-s21995-khairianno1741\&q=Lingkungan

Noor, M. (2001). Peatland Agriculture Potentials and Obstacles. Publisher Kanisius. Yogyakarta.

Panshin, A.J., and C. de Zeeuw (1980). Textbook of Wood Technology. Mc Grow Hill Company. New York.

Regency Government of Kapuas (2009). Kapuas the city of water. Retrieved March 32009 from www.kapuas.net/content/view/30/.

Quinn, F.C., Cowley, K.J., BarlowA, B.A. and Thiele, K.R. (1998). New names and combinations for some Melaleuca (Myrtaceae) species and subspecies from the south-west of Western Australia considered rare or threatened. Nuytsia 8 (1998) : 3.

Rachmanady, D., Lazuardi, D. and Tampubalon, P.T. (2004). Nursery Techniques and Gelam Seed Information. Center for Development of Biotechnology and Tree Improvement 2003. Yogyakarta.

Sayuto, S. (2004). Technical Design and Model of Peat Swamp Forest and Land Rehabilitation in Central Kalimantan. Proceedings of the Scientific Seminar on Technology Readiness to Support Peat Swamp Forest and Land Rehabilitation in Central Kalimantan. Palangkaraya. pp 12.

Scurfield, G. and Segnit, E.R. (1984). Petrifaction of Wood by Silica Minerals. Sedimentary Geology, Volume 39. Issues 3 - 4 (May 1984) : 149-167.

Scheffer, T.C. (1987). Microbiological Degradation and the Causal Organisms. (A chapter in Nicholas, D.D. Wood Deterioration and Its
Prevention by Preservative Treatments). Translator Haryanto Yoedoedibroto. Airlangga University Press. Yogyakarta

Sudjana (2002). Design and Analysis of Experiment. $3^{\mathrm{Ed}}$. Publisher Tarsito. Bandung.

Sulthoni, A. (1988). A Study on Bamboo Preservation Traditionally to Prevent Beetle Attack. Disertasi. Forestry Faculty, Gadjah Mada University. Yogyakarta. pp.174

Supriyati, W., Prayitno, T.A., Soemardi, ang Marsoem, S.N. (2013). MechanicalPhysical Properties of Gelam Wood Buried in Peat Soil Swamps on Three Diameter Classes. Bionatura. 15.3 (2013) : 165-169.

Zhang, S.Y. (1996). The Wood DensityMechanical Property Relationship at Species Level. Wood Science Technology 31 : 181-191. 